\title{
nature
}

\section{Europe in trouble over aviation}

\section{Europe's failure to make a common market of itself is typified by the continuing muddle over civil air transport policy. The time has come to change that.}

Tili: European Community is miscalled the "common market" So much is clear from the evidence that repeatedly comes to light of how its tolerance of restraints on free trade are crippling for the economy of Europe (see, for example, Nature 322, 2; 1986). But most of the time, the scale of this self-inflicted damage is hard to assess. Even the brashest of economists would be at a loss to tell what price Europe pays for its decision to forgo the benefits of a sensible division of labour among competing companics in ficlds such as electronics or general manufacturing. But in air transport the disbenefits are conspicuous.

Most European governments maintain civil airlines ostensibly as a means of enabling private persons to move from one place to another. but then come to regard them as extensions of the national persona, along with their national anthems and national flags. Europeans pay for these conceits in two ways: by extra taxes which allow governments to subsidize national airlines, and then by the higher fares which also partly compensate for inceficiency. It is especially scandalous that the European Commission should for so long have tolerated a state of affairs that cramps what should be one of the essential elements of the Europe it secks, people's freedom to move about. It is similarly outrageous that the benefits of a now-traditional technology should be so widely withheld from 300 million people.

$\mathrm{Now}$, luckily, some governments are becoming restive, with the (ommission showing signs of waking up to its responsibilities. Motives are, inevitably mixed. The British government, which has been pressing for reform for the best part of three vears. is eager that its own nationalized airline, which has been forced by the deprivations of recent years to become efficient and which is about to be sold as a going concern, should be able to compcte more freely for the untapped market in European air travel. It would also be a legislative convenience if the government, when "privatizing" British Airways, were able to dispense with the usual monopolies by saying that competition is free. (There are at least two other privately held British airlines that could compete more effectively if allowed.) The Netherlands govermment is in a similar condition. eager that aviation should become a business rather than a branch of government.

The crucial step that may eventually unlock the jam is that the European Court has ruled that the Treaty of Rome, which created the "common market" in the first place, applies to aviation as to other kinds of business. At last, the Commission seems to have woken up. There is now talk that it will be writing to European airlines, possibly this week, with a warning that they must stop price-rigging and their other restrictive practices. The snag is that the Commission's only sanction is to take offending companies to the courts. not a speedy remedy. That is why hopes still centre on the prospect of a deal between the governments.

But what? The difficulty is that even the most fervent advocates of liberalized European air traffic seem to shrink from outright deregulation. Even the visionaries suppose that air traffic within the ten member states of the Community will continue to be regulated by a series of bilateral agreements between governments, so that aircraft bound from, say. Rome (1) London calling at Paris will not be free to pick up extra passiengers on the second leg of their flight unless that right has been separately negotiated. Instead, the hopefuls model their ambitions on the present agreements between the British government and those of The Netherlands and Belgium, which allow all airlines to fly between designated point at the frequencies they choose, and with whatever fares they fix, provided that both governments choose not to object. These arrangements are better than nothing, but fall short of what they might be. What Europe needs, in this connection as in others, is true competition. In particular, it should be understood that subsidizing airlines is as illegal as subsidizing, say, motor manufacturers (for, otherwise, wasteful carriers will be perpetuated), that airlines of any European nationality may fly between any pair of cities already connected by scheduled services and that there should be no restraint on the ownership, within Europe, of privately held airline companies. That is what the airline business will have to come to in the end. The European Commission should face up to that now, not later. Until it does, the benefits of a simple technology will remain in escrow.

\section{Broadcasting by numbers}

Another British government has failed again to find a way of living without the $B B C$.

Ir we have enemies like that, what need have we of friends? That must be the reaction of the British Broadcasting Corporation $(\mathrm{BBC})$ to last week's report of the committee under Professor Alan Peacock set up just over a year ago to find politically more palatable ways of supporting British public broadcasting. which is at present done by requiring those who use television receivers to buy an annual licence to make the practice legitimate. The Peacock committee came into being to spare the present government and its successors (of all parties) the periodic problem of deciding how much the licence fee should be. which is politically as popular as deciding by what degree politicians' salaries should be increased. The present government's suspicion (conviction?) a year ago was that advertising was the answer.

Expectations have not been realized. Peacock says that there is not enough advertising to sustain both public service broadcasting and the commercial stations. That is why the BBC is temporarily relieved. But then the committee goes off in a quite unexpected and technological direction. saying that the problem of financing the BBC independently of government decisions about a licence fee will be solved in the distant future. when it becomes possible to ensure that people pay each time they watch a television programme put out by the public broadcasting network. To the Peacock committee, it seems a minor matter that the technology for bringing this about, easily designed on the back of an envelope, is still far beyone most manufacturers ${ }^{\circ}$ ken. It is nevertheless odd that a committee apparently willing to accept its marching orders, to devise alternative financing. should have sought refuge in technological futurology from the awkward truth that free-market remedies in present circumstances would kill standards. It would have been better to say outright that the BBC. for all its many faults, is probably worth keeping the way it is. 